\title{
DNA immunization targeting carcinoembryonic antigen in colorectal cancer patients
}

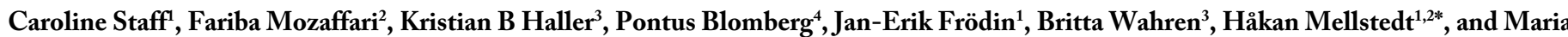 \\ Liljefors ${ }^{1}$ \\ ${ }^{1}$ Department of Oncology and Pathology (Radiumhemmet), Cancer Center Karolinska, Karolinska Institute, Karolinska University Hospital at Solna, Sweden \\ ${ }^{2}$ Immune and Gene Therapy Laboratory, Cancer Center Karolinska, Karolinska Institute, Sweden \\ ${ }^{3}$ Department of Microbiology, Tumor and Cell Biology, Karolinska Institute, Sweden \\ ${ }^{4}$ Clinical Research Center and Vecura, Karolinska University Hospital, Sweden
}

\begin{abstract}
Active specific immunotherapy targeting carcinoembryonic antigen (CEA) may induce antigen-specific humoral and cellular responses in cancer patients. Plasmid DNA, encoding tumor antigens, represents a novel approach of delivering conformational antigens. Here we report immune data of an explorative study using CEA66-DNA (non-glycosylated cytoplasmic CEA) and tetwtCEA-DNA (wild type glycosylated and secreted CEA) for immunization in combination with cyclophosphamide and GM-CSF in the adjuvant setting of radically operated colorectal cancer (CRC). 10 patients received intradermal (id) or intramuscular (im) CEA66-DNA delivered by needle-free Biojector at weeks 0, 2, 6 (part 1). 10 patients received tetwtCEADNA id by needle injection and electroporation at weeks 0 and 12 (part 2). In part 3, 6 patients were primed with CEA66-DNA and boosted with tetwtCEA-DNA. A significant increase of CD4 ${ }^{+}$effector memory, CD8 ${ }^{+}$ effector and $\mathrm{CD}^{+}$effector memory $\mathrm{T}$ cells was seen in part 1 . An immune response against CEA atleast one time point was noted in $15 / 20$ (75\%) patients in parts 1 and 2 together. The frequency of patients mounting a CEA-specific cellular immune responses was significantly higher in part 1 (100\%) than in part 2 (50\%) ( $\mathrm{p}=0.03)$. In part 3,5/6 (83\%) patients showed a CEA-specific immune response after a prime-boost protocol. The higher CEA-specific T cell responses seen in part 1 , may indicate reduced immunological tolerance induced by the non-glycosylated intracellularly produced CEA66-DNA immunogen. Humoral responses determined by ELISA were low. Further studies are warranted to optimize vaccination schedules to induce both cellular and humoral anti-CEA responses of clinical significance.

Clinical trials.gov.identification number (parts 2/3) is NCT01064375.
\end{abstract}

\begin{abstract}
Abbrevations
CEA: Carcinoembryonic Antigen; CRC: Colorectal Carcinoma; DFS: Disease free survival; ELISA: Enzyme-linked immunosorbent assay; ELISPOT: Enzyme-linked immunospot; EP: Electroporation; GM-CSF: Granulocyte-macrophage colony-stimulating factor; HRP: Horseradish peroxidase; id: intradermal; IFN- $\gamma$ : interferon $\gamma$; IL-4: Interleukin-4; IL-10: Interleukin-10; im: Intramuscular; OS: Overall survival; PBMC: Peripheral blood mononuclear cells; PBS: Phosphate buffered saline; PHA: Phytohemagglutinin; PPD: Purified protein derivative of tuberculin; sc: Subcutaneous; SI: Stimulation index; SIIR: Sustained induced immune response; STIIR: Single time point induced immune response; TAA: Tumor associated antigens; TCV: Therapeutic cancer vaccines; TNF- $\alpha$ : Tumor necrosis factor- $\alpha$
\end{abstract}

\section{Introduction}

Colorectal carcinoma (CRC) is a major cause of cancer-related mortality. Despite introduction of new drugs, a large proportion of patients remain incurable. Adjuvant chemotherapy is standard for the treatment of stage III colon cancer and increases the 5-year survival rate to more than $70 \%$ and is routinely also used in stage II colon cancer patients with high-risk of relapse. Several chemotherapeutic agents approved for metastatic CRC have however failed to improve the prognosis for patients with stages II and III CRC [1]. New therapeutic approaches are needed and immunotherapy may offer a novel targeted therapeutic option [1].
The goal of therapeutic cancer vaccines (TCV) is to induce a robust long-lasting immune response with limited toxicity [2]. Most tumor cells express tumor-associated antigens (TAA), which might act as targets for the immune system [3]. A commonly expressed TAA in gastrointestinal cancer is the carcinoembryonic antigen (CEA) which has been explored in immunotherapy trials [4-11]. Vaccination targeting CEA in humans was shown to induce antigen-specific humoral, $\mathrm{CD}^{+}$helper as well as $\mathrm{CD} 8^{+}$cytotoxic T-cell (CTL) responses [8,11-14].

Immunisation with proteins comprising multiple $\mathrm{CD} 4^{+}$and $\mathrm{CD} 8^{+}$ $\mathrm{T}$ cell epitopes, have failed to induce a robust $\mathrm{CD} 8^{+}$response which may partly be explained by defect peptide processing of exogenous proteins not entering the MHC class I antigen presentation pathway. DNA contains immunostimulatory $\mathrm{CpG}$ sequences that stimulate cytosolic DNA-sensing pathways, interferon regulatory factors and Fas-FasL

Correspondence to: Håkan Mellstedt, $\mathrm{MD}, \mathrm{PhD}$, Prof, Department of Oncology and Pathology (Radiumhemmet), Cancer Centre Karolinska, Karolinska University Hospital Solna, SE-171 76 Stockholm, Sweden, Tel: +46851774641; E-mail: hakan.mellstedt@karolinska.se

Key words: adjuvant, CEA, colorectal cancer, DNA vaccine, electroporation, immune response

Received: April 02, 2017; Accepted: April 26, 2017; Published: April 29, 2017 
interactions [15-17]. A plasmid DNA vaccine acts by in vivo protein synthesis, which increases the possibility to activate innate and utilize MHC classes I and II antigen presenting pathways to induce humoral as well as $\mathrm{CD}^{+}$and $\mathrm{CD}^{+}$antigen specific $\mathrm{T}$ cell responses $[5,18,19]$. DNA vaccines thus offer opportunities to incorporate genes encoding molecules aimed to increase both innate and adaptive immunities to weak TAA $[18,20,21]$.

Recently, DNA immunization was indicated to induce regression of early lesions of papilloma-induced cancer in situ (CIN) where it is likely that cell mediated immune reactivity plays a role. Early genes of human papilloma virus (HPV) 16 and 18 given by electroporation to individuals with CIN2/3 lesions appeared to influence differentiation and cause regression to CIN1 or normal pathology in $53-55 \%$ of patients compared to $12-19 \%$ in a placebo group [22].

Our tumor-related CEA-DNA vaccine constructs carrying immunomodulatory tet genes were further modified for expression at different cellular sites [23,24]. The CEA66-DNA vaccine construct encodes a modified, full-length, non-glycosylated form of CEA which is primarily retained in the cells $[25,26]$. In preclinical studies, predominantly $\mathrm{T}$ cells but also antibody responses against CEA glycoprotein were seen using a needle-free immunization device (Biojector) [25,27]. The tetwtCEA-DNA construct encodes wild type glycosylated CEA which is membrane bound and then secreted $[25,26]$. In preclinical studies, strong $\mathrm{T}$ cell as well as antibody responses were induced $[25,27]$.

Technologies to deliver DNA impact the outcome of genetic vaccination. Delivery of DNA vaccines either by intramuscular (im) or intradermal (id) administration by electroporation (EP) increases DNA uptake and antigen expression compared to needle injections [28-30]. Electroporation delivers very short electrical pulses at the site of vaccination, pulses which create transient pores in adjacent cell membranes augmenting the transfection of plasmid DNA and causes a mild inflammation with recruitment of antigen-presenting cells without affecting persistence or integration of the plasmid [23,30,31].

In the present study, we evaluated the immunogenicity of two plasmid CEA-DNA constructs, CEA66-DNA and tetwtCEA-DNA, in CRC patients with no macroscopic disease. Immunization was combined with GM-CSF to further enhance antigen presentation and with cyclophosphamide to reduce immunosuppression $[13,32,33]$.

\section{Materials and methods}

\section{Study design}

The study (ClinicalTrials.gov identifier, NCT01064375, parts 2/3) was a single-centre exploratory open label trial. The primary objective was to determine safety [34] of CEA-DNA vaccination. The secondary objectives were to compare CEA66-DNA id delivery with im delivery using Biojector and tetwtCEA id delivery with electroporation as well as to assess the efficacy of heterologous priming with CEA66-DNA followed by boosting with tetwtCEA-DNA. All patients provided a written informed consent prior to the study. The trial was approved by the Regional Ethical Review Board, Stockholm, Sweden and by the Medical Products Agency, Uppsala, Sweden.

\section{Study population and eligibility criteria}

Details regarding eligibility criteria have been described elsewhere [34]. Briefly, patients were eligible if they had undergone a complete resection of a colonic or rectal cancer, histologically confirmed stage II or III without evidence of remaining macroscopic disease. Ten patients were enrolled in part 1 (cohorts I/II) and part 2 (cohorts III/IV), respectively (Table 1) [34]. Six patients from part 1 were enrolled in part 3 (cohort V). Median time from primary surgery to enrollment was 16 months (range 14-67 months). Median follow-up time for all patients was 23 months (range 12-38 months). Basic clinical characteristics are shown in Table 1. All patients, except two, were evaluable for immune responses according to the protocol.

\section{Production of DNA vaccines}

Two different CEA (CEACAM5)-expressing DNA plasmids were modified, one expressing CEA in the cytoplasm (CEA66-DNA, batch no. 060118-24:1/31) to improve antigen presentation for class I peptides and induction of cellular immunity, the other to improve the antibody production by secretion of the CEA antigen (tetwtCEADNA, batch no. 090819-24:2/51) [35,36]. Both constructs were fused

Table 1. Characteristics of the patients.

\begin{tabular}{|c|c|c|c|c|c|}
\hline & \multicolumn{2}{|c|}{ Part 1} & \multicolumn{2}{|c|}{ Part 2} & \multirow{2}{*}{$\frac{\text { Part 3* }}{\mathrm{V}}$} \\
\hline & I & II & III & IV & \\
\hline Study cohort & $(n=5)$ & $(n=5)$ & $(n=5)$ & $(n=5)$ & $(n=6)$ \\
\hline Age, years $($ mean $\pm \mathrm{SD})$ & $64.8 \pm 6.6$ & $62.8 \pm 8.5$ & $58 \pm 9.2$ & $66 \pm 8.3$ & $67 \pm 5.6$ \\
\hline \multicolumn{6}{|l|}{ Gender, n (\%) } \\
\hline Male & $3(60)$ & $3(60)$ & $2(40)$ & $5(100)$ & $4(67)$ \\
\hline Female & $2(40)$ & $2(40)$ & $3(60)$ & $0(0)$ & $2(33)$ \\
\hline \multicolumn{6}{|l|}{ Tumor site, n (\%) } \\
\hline Colon & $4(80)$ & $4(80)$ & $2(40)$ & $4(80)$ & $6(100)$ \\
\hline Rectum & $1(20)$ & $1(20)$ & $3(60)$ & $1(20)$ & $0(0)$ \\
\hline \multicolumn{6}{|l|}{$\mathrm{AJCC}^{* *}, \mathrm{n}(\%)$} \\
\hline II & $3(60)$ & $2(40)$ & $4(80)$ & $3(60)$ & $3(50)$ \\
\hline III & $2(40)$ & $3(60)$ & $1(20)$ & $2(40)$ & $3(50)$ \\
\hline \multicolumn{6}{|l|}{ Previous therapy except surgery, n (\%) } \\
\hline Preoperative $\mathrm{RT}^{* * *}$ & 0 & 0 & $1(20)$ & $1(20)$ & 0 \\
\hline Preoperative radiochemotherapy & $1(20)$ & 0 & 0 & 0 & 0 \\
\hline Adjuvant chemotherapy & $3(60)$ & $4(80)$ & $2(40)$ & $3(60)$ & $5(83)$ \\
\hline Preoperative RT and Adjuvant chemotherapy & 0 & $1(20)$ & $2(40)$ & 0 & 0 \\
\hline None & $1(20)$ & 0 & 0 & $1(20)$ & $1(17)$ \\
\hline
\end{tabular}

* Part 3 includes 6 patients from part 1.

** AJCC: staging by American Joint Committee on Cancer (5th Edition)

*** RT: Radiotherapy 
to nucleotides representing amino acids $830-844$ of tetanus toxoid (QYIKANSKFIGITEL), a strong promiscuous helper T cell epitope, to improve immunogenicity of endogenous CEA, which is a weak immunogen $[21,24]$. The CEA66-DNA plasmid construct has the Nand C-terminal signal sequences of the CEA gene deleted, no posttranslational glycosylation of the CEA66 protein product and is mainly located in the cytoplasm [22-24]. The tetwtCEA protein product has characteristics of the wild-type CEA protein, such as beeing heavily glycosylated and localizing to the expressing cell membrane [22-24]. All DNA vaccines had a concentration of $2 \mathrm{mg}$ DNA/ml. The plasmids were manufactured according to GMP standards by Vecura at the Clinical Research Center, Karolinska University Hospital at Huddinge, Sweden.

\section{Vaccination schedules}

An overview of the different immunization treatments and the number of patients included in the different cohorts is shown in Figure 1 and Table 1 , respectively.

The vaccination schedule of CEA66-DNA delivered id or im by Biojector has been described previously [34]. In part 2, the patients received 400 ug of tetwtCEA-DNA id by needle followed by electroporation. Without or with, recombinant human GM-CSF (sargramostim, Leukine ${ }^{\oplus}$, Bayer Health Care Pharmaceuticals, Seattle, USA). The lower DNA dose was motivated by data that electroporation will deposit plasmids more effectively intracellularly than needle only [23].In part 3, six patients originated from individuals of part 1. In addition to their priming by CEA66-DNA, they were boosted by 400

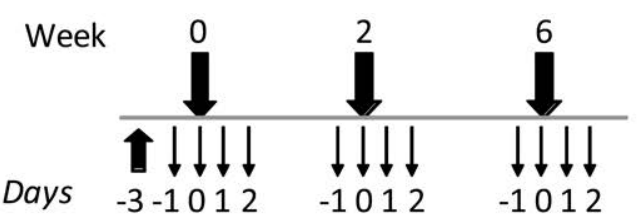

\begin{tabular}{lllll}
\hline Vaccine / adjuvant & & Dose & Route & Site \\
\hline CEA66 & 2or $8 \mathrm{mg}$ & i.d. or i.m. & $*$ \\
GM-CSF & $\downarrow$ & $150 \mu \mathrm{g}$ & i.d./s.c. & $\begin{array}{l}\text { Same site as the } \\
\text { vaccine }\end{array}$ \\
Cyclophosphamide & $\mathbf{3}$ & $300 \mathrm{mg} / \mathrm{m}^{2}$ & i.v. & \\
\hline
\end{tabular}

* Left arm deltoid, right arm deltoid and left thigh region

$1(\mathrm{~A})$

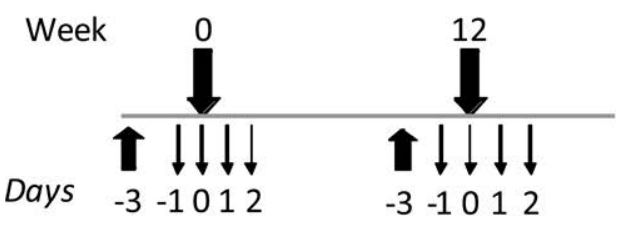

\begin{tabular}{lllll}
\hline Vaccine / adjuvant & Dose & Route & Site \\
\hline tetwtCEA & $400 \mu \mathrm{g}$ & i.d. & $*$ \\
GM-CSF & $150 \mu \mathrm{g}$ & i.d./s.c. & $\begin{array}{l}\text { Same site as the } \\
\text { vaccine }\end{array}$ \\
Cyclophosphamide & 1 $300 \mathrm{mg} / \mathrm{m}^{2}$ & i.v. & \\
\hline
\end{tabular}

* Left arm deltoid, right arm deltoid

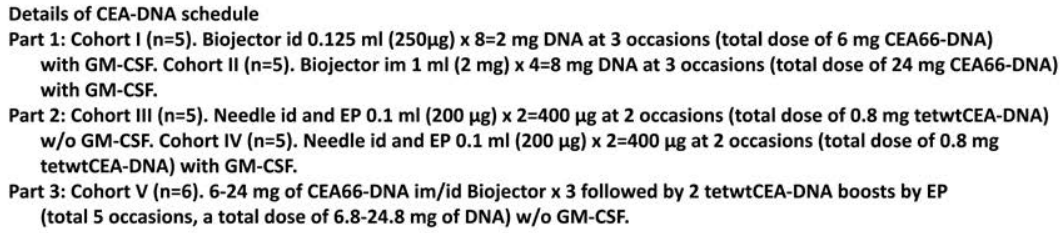

$1(\mathrm{~B})$

Figure 1. A) Schematic presentation of vaccination schedules. Part 1 (cohorts I and II): Patients received one infusion of cyclophosphamide i.v. prior to start of immunization, i.e. day -3 . GM-CSF was given for 4 consecutive days starting day -1 . The vaccine (CEA66-DNA) was given intradermally or intramuscularly by Biojector, weeks 0 , 2 and 6. B) Parts 2 and 3: All patients received one infusion of cyclophosphamide i.v. prior to each immunisation procedure. Patients in part 2 (cohorts III and IV) and part 3 (cohort V) received two intradermal injections of tetwt CEA-DNA (weeks 0 and 12) followed by electroporation. GM-CSF was given for 4 consecutive days starting the day before the vaccine was delivered to cohort IV. 
ug of tetwtCEA-DNA twice, similar to part 2. Due to safety concerns, GM-CSF was omitted from the vaccination schedule in cohort [34].

\section{Delivery of CEA-DNA}

The delivery procedure of CEA66-DNA by the Biojector device (Bioject Medical Technology Inc., Tualatin, OR, USA) has previously been described [34]. After id injection of tetwtCEA-DNA, EP was applied using the DERMA VAX ${ }^{\mathrm{TM}}$ electroporation system (CCEP40A Waveform Generator, Cyto Pulse Sciences, Inc., Glen Burnie,MD, USA; later Cellectis, Paris, France) according to manufacturer's recommendation [37].

\section{Clinical examination and Follow-up}

Before immunization, a complete case history, physical examination and laboratory tests were performed. Patients had planned visits at weeks $0,2,6,8,18,30$ and 72 in part 1 and at weeks 0 , $2,11,12,14,24,36,52$ and 72 in parts 2 and 3. Injection site inspection, physical examination, review of the memory aid and adverse event assessments were done. Standard urine and blood chemistry analysis as well as thyroid function and serum CEA were measured at baseline and throughout the study period. Chest X-ray or computer tomography (CT) as well as CT scan of the abdomen were performed at baseline and during follow-up at the discretion of the physician. The study period was 72 weeks during which the patients were monitored for safety and immune responses (immune responses in parts $2 / 3$ only for 36 weeks). The patients were followed clinically for a total period of 5 years. Disease free survival (DFS) and overall survival (OS) were recorded. DFS survival was defined as time from start of immunization to local recurrence, metastasis or death during last follow-up. OS was defined as time from start of immunization to death or last follow-up [38].

\section{Immune function testing}

Immune responses against a recombinant baculovirus produced CEA protein (rCEA) (Protein Science Corp, (cat.no.3000)) were analysed. Furthermore, as the CEA molecule is characterized by several domains [N-A1-B1-A2-B2-A3-B3-M], a pool of CEA peptides consisting of 15 -mer peptides with 11 aa overlap covering the A3 region, a pool of 15-mers peptide with 10 aa overlap covering the B3 region and the CAP-1 peptide (aa 571 YLSGANLNL) were also used to stimulate $\mathrm{T}$ cells $[36,38-41]$. The CAP-1 peptide which is immunodominant for CEA-reactive $\mathrm{CD} 8^{+} \mathrm{CTL}$ induces CAP1-specific $\mathrm{T}$ cells after immunization of patients with the peptide and various immunostimulating agents during chemotherapy [39]. All peptides were produced by Thermo Hybaid GmbH, Ulm, Germany to a purity of more than $90 \%$.

\section{Isolation of blood mononuclear cells}

Peripheral blood mononuclear cells (PBMC) were isolated by FicollPaque plus (GE healthcare life Science) (cat.no. 17-1440-03)) gradient centrifugation and resuspended in complete medium (RPMI-1640 [Gibco-BRL, cat.no.11-875-093] supplemented with L-glutamine (2 $\mathrm{mM}$ ) (Gibco-BRL, cat.no.25030149), penicillin (100 IE), streptomycin $(100 \mu \mathrm{g} / \mathrm{ml})$ ( Gibco-BRL, cat.no.15140-122) and 10\% heat-inactivated human $\mathrm{AB}$ serum as previously described [42].

\section{Proliferation assay}

PBMC, $1 \times 10^{5}$ cells/well, were cultured with $\mathrm{rCEA}(1$ and $10 \mu \mathrm{g} / \mathrm{ml})$, purified protein derivative of tuberculin (PPD) $(2.5 \mu \mathrm{g} / \mathrm{ml})$ (National Serum Institute, cat.no.2390) and phytohemagglutinin (PHA) $(10 \mu \mathrm{g} /$ ml) (Sigma-Aldrich cat.no.L8902) in 96-well culture plates for 6 days.
During the last 18 hours of incubation, $1 \mu \mathrm{Ci} /$ well of $[3 \mathrm{H}]$ thymidine (Perkin Elmer, cat.no.NET2700) was added. Cells were harvested and incorporated radioactivity measured by a beta-counter (Micro Beta Trilux, Wallac, Finland). Results are shown as stimulation index (SI) calculated by dividing mean radioactivity $(\mathrm{cpm})$ of 6 replicates of experimental wells by that of the background value (cells with medium alone). CEA responses were also analyzed in eight healthy donors: SI

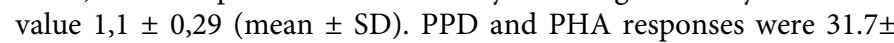
27.9 and $15.4 \pm 12.5$ resp. Changes in PPD and PHA activity over time in patients are presented as ratios between post and prevaccination values. A change in the ratio of $\geq 2$ on at least two occasions, compared to baseline, was considered significant.

\section{ELISPOT assay}

PBMC were cultured in 48 -well plates with $\mathrm{rCEA}(1$ and $10 \mu \mathrm{g} / \mathrm{ml})$, the pool of CEA peptides, $(5 \mu \mathrm{g} / \mathrm{ml})$, PHA $(5 \mu \mathrm{g} / \mathrm{ml})$ or PPD $(2.5 \mu \mathrm{g} / \mathrm{ml})$ for 5 days. A millipore 96-well filter plate was coated with anti-IFN- $\gamma$ antibody $(10 \mu \mathrm{g} / \mathrm{ml})$ (Mabtech, cat.no.3420-3-250). Cultured PBMC were transferred to the coated plate and incubated for $20 \mathrm{~h}$ with the antigens as above. Cells were washed and incubated with a secondary biotinylated anti-IFN- $\gamma$ antibody $(1 \mu \mathrm{g} / \mathrm{ml})$ (Mabtech, cat.no.3420-6250) for $2 \mathrm{~h}$ at room temperature. After washing, a streptavidin-ALP conjugate (1:1000) (Mabtech, cat.no.3310-9) was added to the cells and incubated for $1 \mathrm{~h}$ at room temperature. Cells secreting IFN- $\gamma$ were developed by adding substrate BCIP/NBT plus (Mabtech, cat.no.365010) and incubated at room temperature. The reaction was stopped at the appearance of dark spots. Spots were counted by an automatic ELISPOT reader (AID, Strassberg, Germany) and results are presented as SFU (spot forming units $/ 10^{6}$ cells). CEA responses were also analyzed in eight healthy donors: SFU $1 \pm 1.4$ (mean \pm SD).

\section{Cytokine secretion assay}

Supernatants from the proliferation assays were collected $(20 \mu \mathrm{l} /$ well) at days 1 and 5 of culture and stored at $-70^{\circ} \mathrm{C}$ until analyzed. IL-4, IL-10, IFN- $\gamma$, TNF- $\alpha$ and GM-CSF were analyzed using the Bio-Plex 200 System (Bio-Rad Laboratories, cat.no.171-000201) according to manufacturer's instruction (http://www.bio-rad.com/webroot/web/ pdf/lsr/literature/4110004F.pdf).

\section{ELISA}

ELISA plates were coated with $0.1 \mu \mathrm{g}$ per well of rCEA (Protein Sciences, Meriden, CT) or purified hCEA (a gift from Prof. S. Hammarström, Umeå University, Umeå) diluted in $0.05 \mathrm{M} \mathrm{Na}_{2} \mathrm{CO}_{3}$ $(\mathrm{pH} 9,6)$ and incubated at room temperature overnight followed by 24 $\mathrm{h}$ in $4^{\circ} \mathrm{C}$. After washing in ELISA buffer $(0.05 \%$ Tween $20,0.15 \mathrm{M} \mathrm{NaCl}$ in distilled water), the plates were blocked with 5\% milk in PBS for $2 \mathrm{~h}$. Serum from immunized patients were diluted in PBS with $2.5 \%$ milk (1:4 - 1:10000) and added to the plates. Following incubation overnight at room temperature, excess serum was removed and the plates were washed with ELISA buffer. To detect CEA-specific IgG antibodies, a rabbit anti-human HRP (Daco, cat.no.P0214) conjugate (1:3000 in $1.25 \%$ milk) was added to the plates and incubated at $37^{\circ} \mathrm{C}$ for $2 \mathrm{~h}$. Plates were washed with ELISA buffer and developed by adding O-phenylene diamine substrate (Sigma-Aldrich cat.no. P9029) activated by $\mathrm{H}_{2} \mathrm{O}_{2}$. The reaction was stopped by adding $2.5 \mathrm{M} \mathrm{H}_{2} \mathrm{SO}_{4}$. Optical density (OD) was read at 490 and $650 \mathrm{~nm}$. A net absorbance of 0.5 was used as a cutoff. A monkey anti-CEA serum served as a positive control.

\section{Monoclonal antibodies}

The following monoclonal antibodies were used in flow-cytometry: 
CD3 (BD, cat.no.557597), CD4 (BD, cat.no. 550631), CD8 (BD, cat. no. 347314), CD25, (BD, cat.no. 555432) CD56 (BD, cat.no.340410), CD45RA (BD, cat.no. 347723), CCR7 (R\&D Systems, cat.no.FAB197P) CD19 (BD, cat.no. 347544) HLA-DR (BD, cat.no. 347367) CD11b (BD Pharmingen, cat.no.562793), CD33 (BD Pharmingen, cat.no.561817), CD14 (BD, cat.no.557923), CD45, (eBioscience, cat.no.9048-9459) and a $\mathrm{T}_{\text {reg }}$ staining kit (Foxp3/CD4/CD25) (eBioscience, cat.no.88-8995-40).

\section{Flow cytometry}

The procedure has been described in detail previously $[43,44]$. Briefly, conjugated antibodies were added to cells $\left(5 \times 10^{5}\right.$ cells/tube) and incubated for $30 \mathrm{~min}$. Intracellular staining was performed using the $\mathrm{T}_{\text {reg }}$ staining kit. After a final wash, cells were resuspended in PBS and events acquired using LSRll (BD Biosciences, San Jose, CA, USA) and analyzed by the FlowJo software (Treestar Inc., Ashland, Oregon, USA).

\section{Immune monitoring}

Blood was drawn for immune tests at baseline and at weeks 8,18 , 30, 72 in part 1 and in parts 2 and 3 at baseline and at weeks 2, 14, 24, 36 .

\section{Definition of vaccine-induced immune responses}

A vaccine-induced proliferative response was fulfilled if there was at least a two-fold increase in SI compared to baseline [45]. A vaccine-induced IFN- $\gamma$ response in ELISPOT was defined as at least a two-fold increase in the delta value (experimental value minus background) compared to baseline [46]. In the cytokine secretion assay, the highest value from $24 \mathrm{~h}$ or $120 \mathrm{~h}$ cultures respectively was used. Concentration of a cytokine in experimental wells was divided with that of the background value (cells with medium alone). An antigen-specific cytokine/chemokine secretion response was defined as a two-fold increase in the concentration of a specific cytokine in a postvaccination sample compared to pre-vaccination sample. A vaccine-
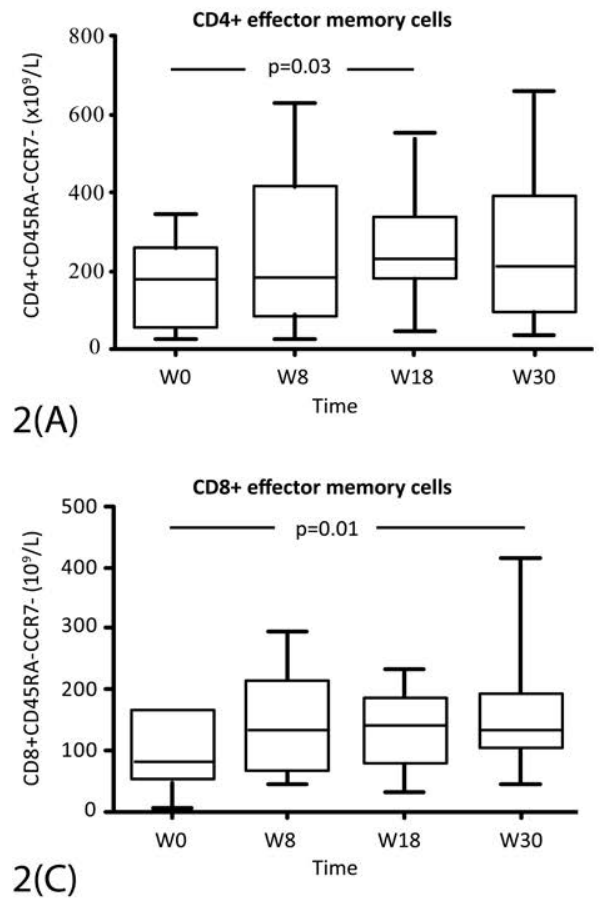

induced anti-CEA IgG antibody response (ELISA) was defined as an increase in the titer of at least two-fold, compared to baseline.

\section{Single time point induced immune response (STIIR)}

A patient was considered to have a STIIR if a response against rCEA and/or CEA derived peptides in one of the assays (proliferation, ELISPOT, cytokine secretion) was noted at only one time point.

\section{Sustained induced immune response (SIIR)}

A patient was considered to have a SIIR if a response in at least in one of the assays (proliferation, ELISPOT, cytokine secretion) was noted at least two different time.

\section{Statistical methods}

Statistical analyses were performed using the IBM SPSS (version 19) and STATVIEW (version 5) statistics. The non-parametric Friedman's test for multiple comparisons was used to calculate relation of cell subsets at different time points. The Chi-square, Fisher test and one-way ANOVA tests were used to analyze differences in prognostic factors between groups and the relation to immune responses. One way ANOVA and Friedman's test were used to assess PPD and PHA responses at baseline comparing patients and healthy donors as well as patients over time. A p-value of $<0.05$ was considered statistically significant.

\section{Results}

\section{Lymphocyte subsets and activation}

No major significant differences in lymphocyte subsets at baseline were noted comparing patients in parts 1 and 2 . However, in comparison to healthy controls, $\mathrm{CD} 4^{+}$and $\mathrm{CD} 8^{+}$memory cells were significantly lower in patients, $\left(\mathrm{p}<0.01\right.$ and $\mathrm{p}<0.05$ respectively) and $\mathrm{CD} 4^{+}$effector memory cells significantly higher ( $\mathrm{p}<0.05$, not shown in figures).

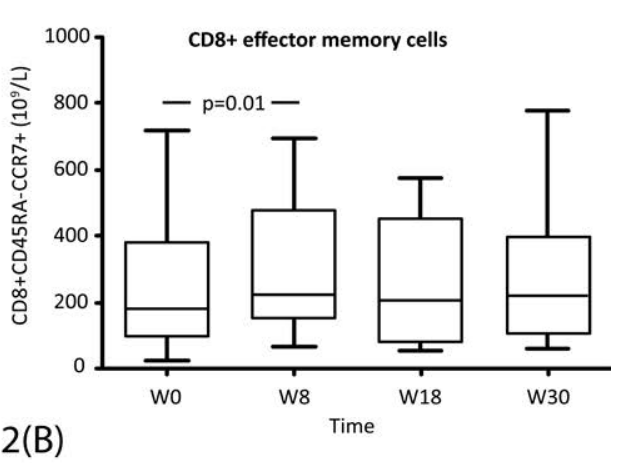

Figure 2. Total numbers ofT cell subsets (x 10\%/1) from start of immunization (week 0) and during follow-up (week 8-30) in part 1 (cohorts I and II). A) CD4 ${ }^{+}$effector-memory cells; B) $\mathrm{CD} 8^{+}$memory cells; C) CD8 $8^{+}$effector-memory cells. The box represents the $25^{\text {th }}$ to $75^{\text {th }}$ percentiles. The line in the middle represents the median. The top whisker is drawn from the value associated with the $75^{\text {th }}$ to $90^{\text {th }}$ percentiles, and bottom from $25^{\text {th }}$ to $10^{\text {th }}$ percentile. P-values are indicated at the top. 
In part 1 , a significant increase was seen in $\mathrm{CD}^{+}$effector memory cells at week $18(\mathrm{p}=0.03)$; in $\mathrm{CD}^{+}$effector cells at week $8(\mathrm{p}=0.01)$ and in $\mathrm{CD}^{+}$effector memory cells at week $30(\mathrm{p}=0.01)$ (Figure 2$)$. No significant changes in those subsets were noted in patients of parts 2 and 3 and neither in $\mathrm{T}_{\text {reg }}$ cells (CD4+CD25highFOXP3+), myeloderived suppressor cells (MDSC) (CD11b+ CD33+HLA-DR-CD14-), NK or NKT cells over time (data not shown).

At baseline, patients had a significantly lower proliferative response to PHA than controls $(\mathrm{p}<0.001)$ but PPD response did not differ significantly. PHA responses over time are shown in Figure 3. A more than two-fold increase compared to baseline at at least two timepoints was noted in 10/26 (38\%) patients. PPD responses increased in $12 / 26$ (46\%) of the patients (data not shown). These increases were distributed among vaccinees, and thus serve to indicate recovery of immunoactivation.

\section{CEA-related immune responses}

Proliferation assays: In part 1 of the study, 4/10 (40\%) patients mounted a CEA specific proliferative response at at least one time point. Responses were detected between weeks 18 and 30. A proliferative response at two time points was seen in 2 patients $(20 \%)$ (Table 2). In part 2, a vaccine-induced proliferative response was seen once in 3/10 (30\%) patients. Responses were detected between weeks 24 and 36. A response at two different time points was not seen. In part 3 , $3 / 6(50 \%)$ patients mounted a vaccine-induced proliferative response between weeks 2 and 24 . A response at two time points was seen in one patient (17\%).

ELISPOT (IFN- $\gamma$ ): A response against rCEA at at least one time point was detected in $7 / 10(70 \%)$ patients in part 1 . Responses were noted between weeks 8 and 72 . A response at two different time points was noted in two of them (20\%) (Table 2). In part 2, a cellular response to CEA at one time point was detected in $2 / 10(20 \%)$ patients between

Table 2. Summary of individual CEA-specific immune responses in individual patients immunized with CEA66-DNA (Part 1 (cohorts I, II)), tetwtCEA-DNA, (Part 2 (cohorts III, IV)) and CEA66-DNA/tewtCEA-DNA part 3 (cohort V).

\begin{tabular}{|c|c|c|c|c|c|c|c|c|c|c|c|c|c|c|c|}
\hline & & \multicolumn{4}{|c|}{ Proliferation (SI) * } & \multicolumn{4}{|c|}{ ELISPOT $* *$} & \multicolumn{4}{|c|}{ Cytokine secretion assay*** } & \multicolumn{2}{|c|}{$\begin{array}{l}\text { Overall induced } \\
\text { immune } \\
\text { response } * * * *\end{array}$} \\
\hline \multicolumn{2}{|c|}{ Patients } & $\begin{array}{l}\text { W8 } \\
\text { rCEA }\end{array}$ & $\begin{array}{l}\text { W18 } \\
\text { rCEA }\end{array}$ & $\begin{array}{l}\text { W30 } \\
\text { rCEA }\end{array}$ & $\begin{array}{l}\text { W72 } \\
\text { rCEA }\end{array}$ & $\begin{array}{l}\text { W8 } \\
\text { rCEA/P }\end{array}$ & $\begin{array}{l}\mathrm{W} 18 \\
\mathrm{rCEA} / \mathrm{P}\end{array}$ & $\begin{array}{l}\text { W30 } \\
\text { rCEA/P }\end{array}$ & $\begin{array}{l}\text { W72 } \\
\text { rCEA/P }\end{array}$ & $\begin{array}{l}\text { W8 } \\
\text { rCEA }\end{array}$ & $\begin{array}{l}\text { W18 } \\
\text { rCEA }\end{array}$ & $\begin{array}{l}\text { W30 } \\
\text { rCEA }\end{array}$ & $\begin{array}{l}\text { W72 } \\
\text { rCEA }\end{array}$ & STIIR & SIIR \\
\hline \multirow{10}{*}{$\bar{\Xi}$} & $\mathrm{I}-01$ & - & - & - & - & $\begin{array}{l}\text { CEA/A3, } \\
\text { CTL }\end{array}$ & CEA/B3 & $-/ \mathrm{A} 3+$ & - & IFN- $\gamma$, TNF- $\alpha$ & IFN- $\gamma$ & - & n.d. & $\mathrm{R}$ & $\mathrm{R}$ \\
\hline & $\mathrm{I}-02$ & - & - & - & - & - & - & - & $\mathrm{CEA} /-$ & - & - & - & n.d. & $\mathrm{R}$ & NR \\
\hline & $\mathrm{I}-03$ & - & - & - & - & - & $-/ \mathrm{A} 3$ & - & - & TNF- $\alpha$ & - & - & n.d. & $\mathrm{R}$ & $\mathrm{R}$ \\
\hline & $\mathrm{I}-04$ & - & 2.48 & 2.71 & - & CEA/A3 & - & - & - & - & - & - & n.d. & $\mathrm{R}$ & $\mathrm{R}$ \\
\hline & $\mathrm{I}-05$ & - & 4.38 & 2.45 & - & CEA/A3 & $\begin{array}{l}\text { CEA/B3, } \\
\text { CTL }\end{array}$ & - & - & IFN- $\gamma$, IL-10 & $\begin{array}{l}\text { IFN- } \gamma, \\
\text { TNF- } \alpha\end{array}$ & - & n.d. & $\mathrm{R}$ & $\mathrm{R}$ \\
\hline & II-06 & - & - & - & - & - & - & - & - & & - & TNF- $\alpha$ & n.d. & $\mathrm{R}$ & $\mathrm{R}$ \\
\hline & II-07 & - & 2.19 & ND & ND & - & - & ND & ND & - & - & - & n.d. & $\mathrm{R}$ & NR \\
\hline & II-08 & - & - & - & - & - & - & - & -/CTL & IFN- $\gamma$ & - & - & n.d. & $\mathrm{R}$ & $\mathrm{R}$ \\
\hline & II-09 & - & - & - & - & - & CEA/- & - & - & - & - & - & n.d. & $\mathrm{R}$ & NR \\
\hline & II-10 & - & - & 4.75 & - & - & - & - & - & - & - & - & n.d. & $\mathrm{R}$ & NR \\
\hline \multirow{10}{*}{ 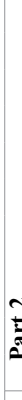 } & III-11 & - & - & - & - & - & - & - & - & - & - & - & - & NR & NR \\
\hline & III-12 & - & - & - & - & - & - & - & - & - & - & - & - & NR & NR \\
\hline & III-13 & - & - & - & - & - & - & - & - & - & - & - & - & NR & NR \\
\hline & III-14 & - & - & 2,0 & - & - & - & CEA & - & TNF- $\alpha$ & - & - & - & $\mathrm{R}$ & $\mathrm{R}$ \\
\hline & III-15 & - & - & - & - & - & - & - & - & TNF- $\alpha$ & TNF- $\alpha$ & TNF- $\alpha$ & TNF- $\alpha$ & $\mathrm{R}$ & $\mathrm{R}$ \\
\hline & IV-16 & - & - & - & ND & - & - & - & ND & - & - & - & - & NR & NR \\
\hline & IV-17 & - & - & 2,7 & - & - & - & - & - & - & - & - & - & $\mathrm{R}$ & NR \\
\hline & IV-18 & - & - & - & - & - & - & - & - & - & $\begin{array}{l}\text { IFN- } \gamma, \\
\text { TNF- } \alpha\end{array}$ & - & - & $\mathrm{R}$ & NR \\
\hline & IV-19 & - & - & - & 3,3 & CEA/B3 & - & CEA/A3 & - & - & - & - & TNF- $\alpha$ & $\mathrm{R}$ & $\mathrm{R}$ \\
\hline & IV-20 & - & - & - & - & - & - & - & - & - & - & - & - & NR & NR \\
\hline \multirow{6}{*}{ 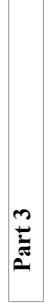 } & $\mathrm{V}-21$ & 2,56 & 2,43 & - & - & - & - & CEA & CEA & - & - & - & - & $\mathrm{R}$ & $\mathrm{R}$ \\
\hline & $\mathrm{V}-22$ & - & - & - & - & - & - & - & - & - & - & - & - & NR & NR \\
\hline & $\mathrm{V}-23$ & 2,7 & - & - & - & - & - & - & - & - & - & - & - & $\mathrm{R}$ & NR \\
\hline & V-24 & - & - & - & - & - & - & - & - & - & - & $\begin{array}{l}\text { IFN- } \gamma, \\
\text { TNF- } \alpha\end{array}$ & TNF- $\alpha$ & $\mathrm{R}$ & $\mathrm{R}$ \\
\hline & V-25 & - & - & - & - & - & CEA & $\begin{array}{l}\text { CEA/ } \\
\text { A3,B3,CTL }\end{array}$ & - & - & - & IFN- $\gamma$ & & $\mathrm{R}$ & $\mathrm{R}$ \\
\hline & V-26 & - & 2,3 & - & - & - & - & - & - & - & - & $\begin{array}{l}\text { IFN- } \gamma, \\
\text { TNF- } \alpha\end{array}$ & $\begin{array}{l}\text { IFN- } \gamma, \\
\text { TNF- } \alpha\end{array}$ & $\mathrm{R}$ & $\mathrm{R}$ \\
\hline
\end{tabular}

*Proliferative response against recombinant CEA (rCEA)

**ELISPOT response against rCEA and CEA derived peptides (P) (A3, B3 or CTL peptide)

***Induced cytokine secretion response against rCEA. Detected cytokines are indicated.IL-4, IL-7, IL-17 and IFN- $\alpha$ secretion were not detected.

****R; Responder. NR; Non-responder

STIIR: Single time point induced immune response

SIIR: Sustained induced immune response

ND: Not done 


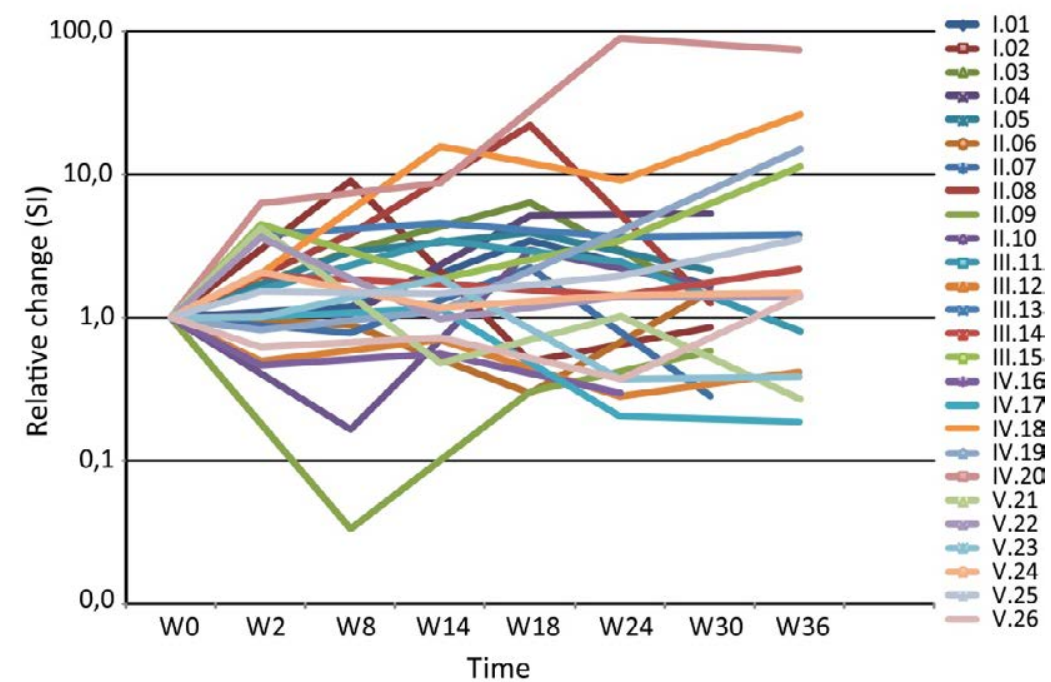

Figure 3. Individualrelative changes in proliferative responses (SI) to PHA from start of immunization (week 0) and during follow-up (weeks 2-36).

weeks 2 and 24 . One of them had a response at two time points. In part 3, 2/6 (33\%) patients mounted an IFN- $\gamma$ response, noted between weeks 14 and 36. Both had a response at least two time points.

Cytokine secretion: In Table 2 the individual cytokine responses against rCEA are summarized. A Th1-like cytokine secretion pattern (IFN- $\gamma$, TNF- $\alpha$ and/or GM-CSF) was noted between weeks 8 and 36. A Th2-like cytokine response (IL-4, IL-10) was rare. The cumulative absolute values of the different cytokines $(\mathrm{pg} / \mathrm{ml})(\mathrm{IFN}-\gamma$, TNF- $\alpha$, GMCSF, IL-4, IL-10) for all individual patients are shown in Supplementary Figure.

Epitope mapping: CEA-derived peptides were used to map epitope responses by ELISPOT. A response against the $\mathrm{A} 3$ peptides was seen in $6 / 26(23 \%)$ patients, against B3 in 4/26 (15\%) and in 4/26 (15\%) against the CTL epitope. In 4 patients, a response against rCEA but not against the peptides was noted. One patient (II-14) had a CTL peptide response but no response against rCEA (Table 2).

Anti-CEA antibody response (ELISA): An anti-CEA IgG antibody response was noted in two patients only. Peak titer increase was 20-fold at week 18 in patient II-08 and 2.5-fold at week 14 in patient IV-18 (data not shown)

Single time point induced immune response (STIIR) (Parts 1 and 2): In total, 15 out of 20 patients (75\%) mounted a STIIR in any of the antigen-specific assays: $10 / 10(100 \%)$ in part 1 and 5/10 (50\%) patients in part 2 . The difference is statistically significant $(\mathrm{p}=0.03)$ (Table 2).

Sustained induced immune response (SIIR) (Parts 1 and 2): An SIIR was seen in 6/10 (60\%) patients in part 1 and in 3/10 (30\%) patients in part 2 . The difference was not statistically significant (Table 2). The duration of CEA specific immune responses in patients with SIIR lasted for several months (Figure 4).

Priming with CEA66-DNA and boosting with tetwtCEA-DNA (Part 3): Six patients from part I who developed an immune response during priming with CEA66-DNA were boosted with tetwtCEA-DNA. $5 / 6(83 \%)$ mounted a STIIR during boosting and 4/6 (67\%) developed a SIIR following these procedures (Table 2).

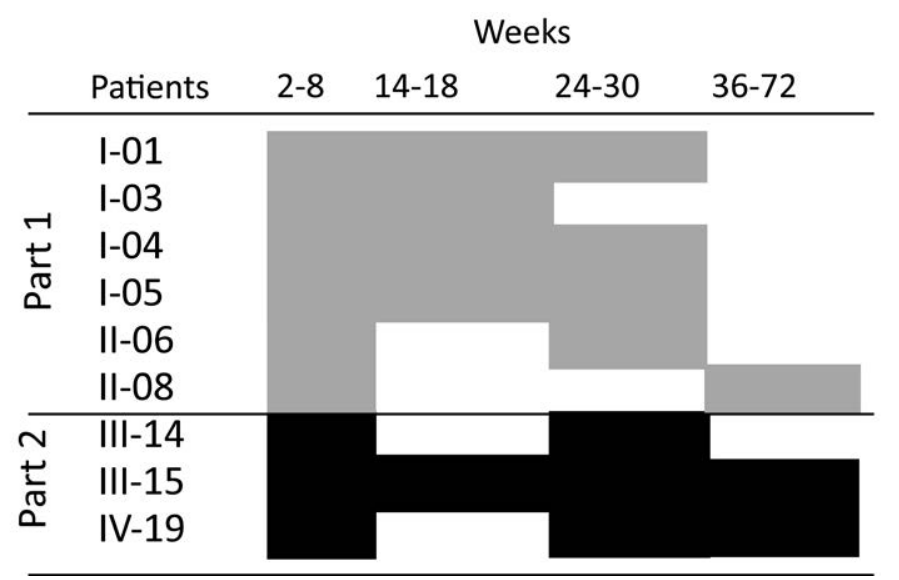

Figure 4. Duration of vaccine induced cellular responses in individual patients with a sustained induced immune response (SIIR) during follow-up (weeks 2-72). (Part 1 ( $\square$ ) and Part $2(\square)$ ).

\section{Clinical tumor status}

Clinical outcome and relation to immune response: There was no significant difference comparing patients in parts 1,2 and 3 with regard to age, sex, stage or differentiation of the primary tumor. Patient II-07 relapsed at month 12 and was still receiving chemotherapy at followup at 25 months. Pat no II-10 had a solitary liver metastasis at month 12. A resection was performed and no signs of relapse were noted at follow-up. In the remaining patients, no evidence of disease recurrence has been noted. Median DFS of all patients in part 1 was 33 months (range 12-50+), and median OS 33 months (range 23-50+). In part 2, no patients have relapsed. Median OS in part 2 was 25 months (range 12-38+ months). There was no significant difference in OS or DFS comparing patients with STIIR or SIIR (data not shown).

Secondary malignancies: During follow-up, one patient (I-03) died at month 23 due to urinary bladder cancer, diagnosed 18 months after start of immunization treatment. Patient II-06 was diagnosed with a superficial urinary bladder cancer at 28 months and was successfully treated with local surgery. Patient IV-16 was diagnosed with a prostatic carcinoma six months after start of treatment and underwent curative treatment. 


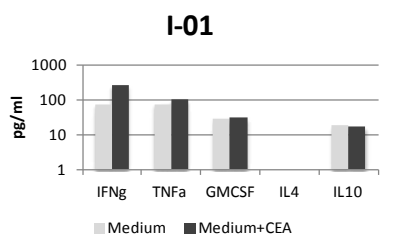

I-03
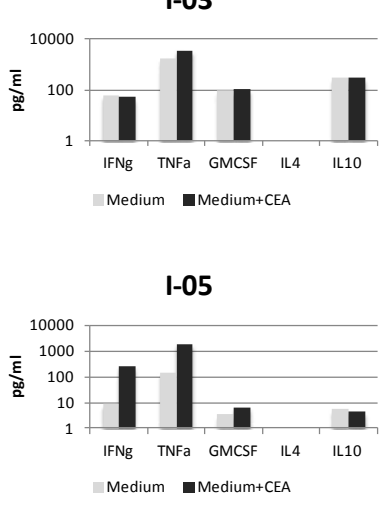

II-07

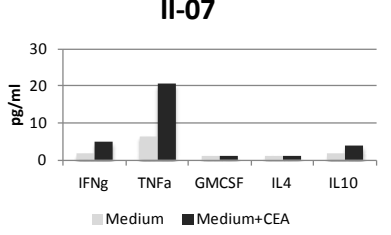

II-09

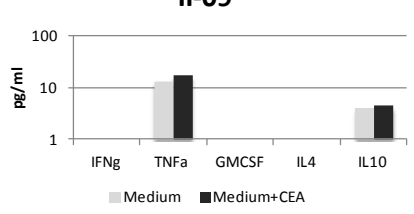

III-11

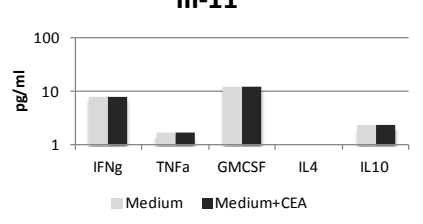

III-13

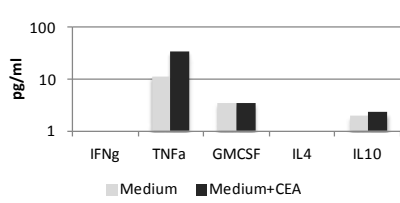

III-15

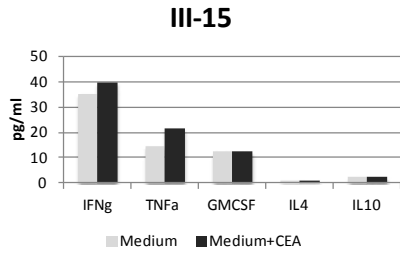

I-02

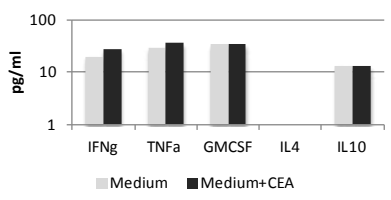

I-04
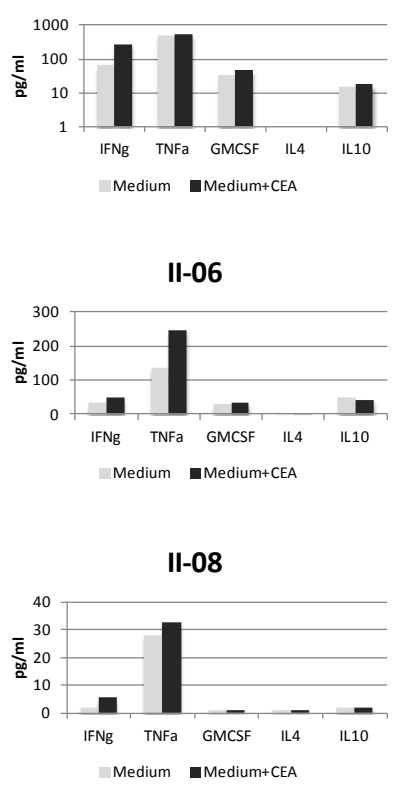

II-10

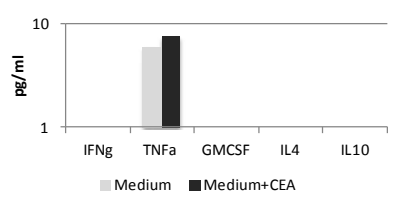

III-12

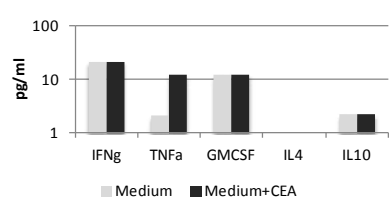

III-14

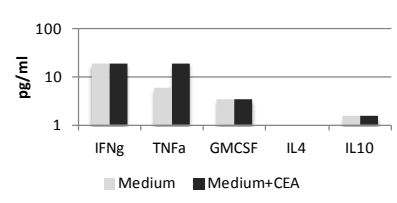

IV-16

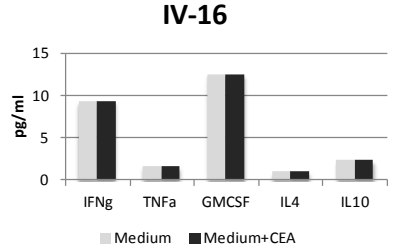


IV-17

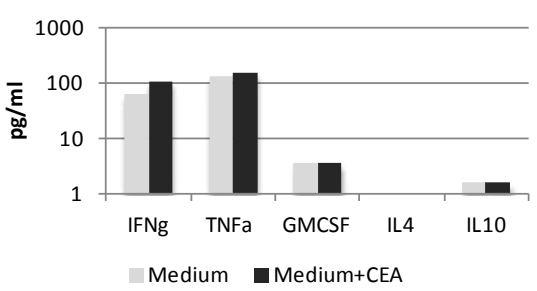

IV-19

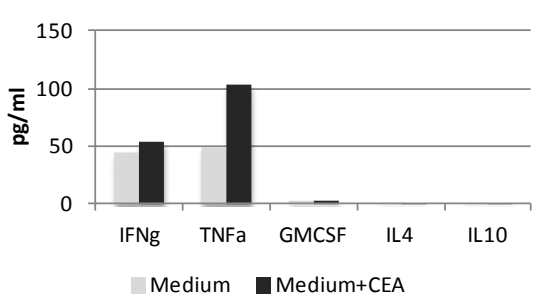

V-21

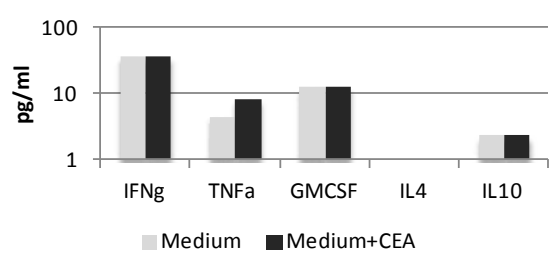

V-23

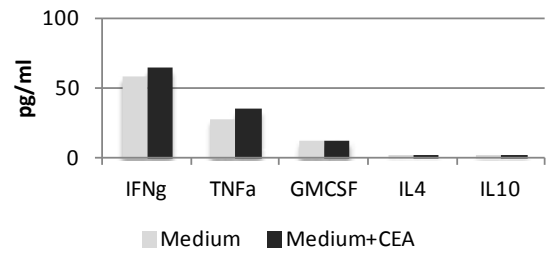

V-25

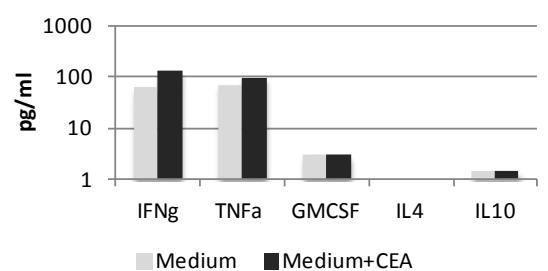

IV-18

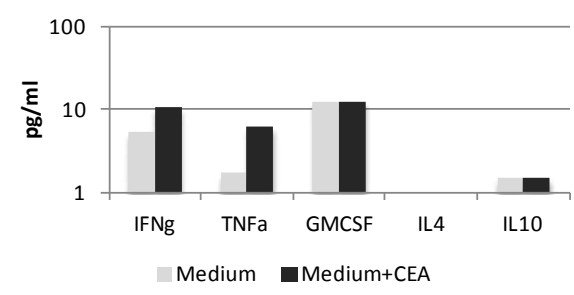

IV-20

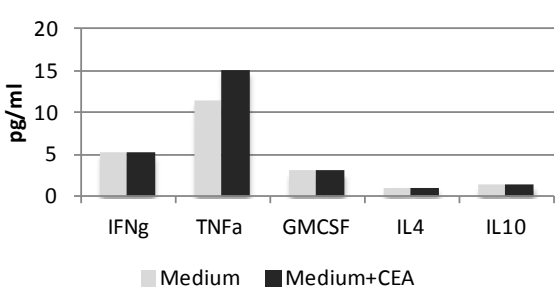

V-22

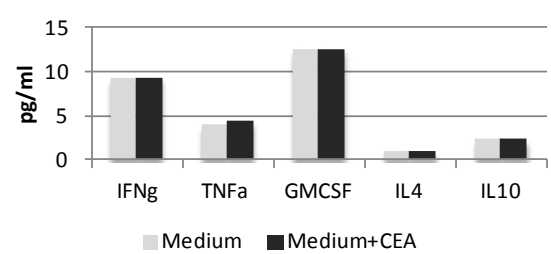

V-24

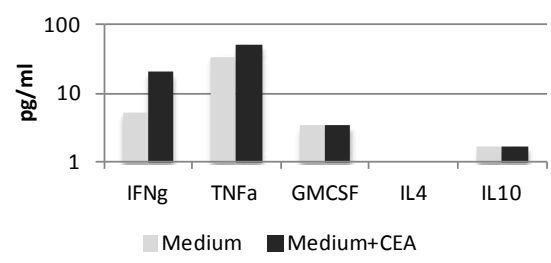

V-26

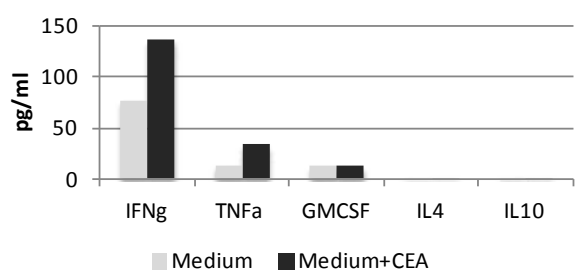

Supplementary Figure.Secretion of Th1 (IFN- $\gamma$, TNF- $\alpha$, GM-CSF) /Th2 (IL-10), cytokines in postvaccination T-cell cultures of individual patients. PMBC were cultured with or without CEA. The highest value from $24 \mathrm{~h}$ and $120 \mathrm{~h}$ cultures respectively was used. Columns represent cumulative mean concentration ( $\mathrm{pg} / \mathrm{ml})^{1}$ from 5-6 different sampling times. 


\section{Discussion}

This is a report on immunogenicity of plasmid CEA-DNA immunization in humans, comprising two different CEA plasmids and two methods of DNA delivery (needle-free jet stream delivery or electroporation). In total, $75 \%$ of patients radically operated for CRC, who had not received previous CEA immunotherapy, mounted detectable CEA-specific immune responses. The responses were however generally weak and revealed cell mediated immunity rather than humoral reactivity. In four of six patients primed with CEA66DNA and boosted with tetwtCEA-DNA, cell mediated responses lasted for several months. This may indicate that CEA66-DNA which is primarily expressed intracellular is more effective in priming a cell mediated immunity than the product of tetwtCEA-DNA which is membrane-bound and secreted. Neither priming with CEA66-DNA nor priming or boosting with tetwtCEA-DNA augmented antibody responses, contradicting preclinical results where antibodies appeared in a non-tolerant host and clinical results with a CEA glycoprotein produced in the baculovirus system $[8,23,25]$.

The CEA molecule in humans, an onco-fetal antigen, occurs in abundance on tumor cells derived from gastro-intestinal tract tumors, but also other cancers such as breast and teratocarcinomas may express CEA [47-49]. In human tumors, CEA is a cell adhesion molecule that belongs to the immunoglobulin superfamily and mediates intercellular contact primarily by the $\mathrm{N}$-terminal IgV-like domain. CEA is therefore thought to contribute to tumor invasion and metastasis [36,50]. Due to its overexpression in tumors, CEA has been targeted both for imaging of primary and metastatic tumors [51-53] and as a therapeutic vaccine in colorectal carcinoma $[6,8-11,14]$.

Our motif for immunizing with both glycosylated and nonglycosylated CEA was that CEA expressed by cancer cells may be nonglycosylated compared to CEA in normal colon cells, rendering the tumor-associated CEA more immunogenic [36]. The tumor associated antigen MUC-1 is frequently hypoglycosylated in myeloma cells and hypoglycosylated MUC-1 was more efficiently processed by dendritic cells inducing a strong $\mathrm{T}$ cell response [54-56]. Slightly heterogenous antigens seem to improve cross-reactivity to endogenous antigens $[57,58]$.

In addition to a cellular immune response against rCEA, immune responses against CEA-derived peptides (A3, B3 and a CTL epitope) were also induced. The cellular immune responses against CEA-derived peptides suggest that CEA66-DNA vaccination induced both $\mathrm{CD} 4^{+}$ and $\mathrm{CD}^{+}$responses, in agreement with studies in mice immunized with CEA66-DNA, where $\mathrm{CD} 4^{+}$cells recognizing the $\mathrm{B} 3$ domain and $\mathrm{CD}^{+}$cells against CTL-epitopes were evoked $[23,27]$.

The route and method of DNA delivery strongly influence the induction of immune responses. We applied the needle-free jet injection device or electroporation to deliver DNA intracellularly for expression of the encoded proteins. In the present study, the frequency of patients mounting a single time point cellular immune response was significantly higher using the needle-free Biojector delivery (part 1) compared to electroporation (part 2). A higher dose of DNA in the Biojector group might also contribute to an augmented immune response explaining the higher frequency of immune responders in part 1 compared to part 2. A better immune response in the Biojector group may also be substantiated by the significant increase of effector/memory $\mathrm{T}$ cells [59]. The Biojector delivery system may also evoke stronger cellular danger signals enhancing the induction of immune responses [19,21]. Immune suppression is a common feature in the tumor microenvironment and a barrier for cancer immunotherapy. Both myeloid and lymphoid regulatory cells in the tumor microenvironment, as well as immunosuppressive factors released by tumor cells might hamper immune responses $[60,61]$. Therapeutic cancer vaccine strategies have to by-pass immune suppression. Monitoring $\mathrm{T}$ cell responses may indicate whether $\mathrm{T}$ cell exhaustion contributes to poor results of immunotherapy [62]. Cyclophosphamide suppresses functions of regulatory $\mathrm{T}$ cells but this type of immunomodulation is early and transient [57,60,63-65]. Nadir levels of regulatory cells are seen within a week but with a rebound after two weeks [66]. No significant change in $\mathrm{T}_{\text {regs }}$ was registered in the present study, which might be due to the fact that $\mathrm{T}_{\text {reg }}$ cells were not monitored sufficiently close to the cyclophosphamide administration.

In the present study, a significantly lower proliferative response to PHA in patients compared to normal controls was noted at start of vaccination. PHA-reactivity increased in about $40 \%$ of the patients during vaccination, a phenomenon which may be related to a reduced suppression induced by the cyclophosphamide treatment, or in the case of part 1, by danger signal activation by the needle-free injections. Our data on memory and effector $\mathrm{T}$ cell populations may also indicate that individuals in part $1 /$ cohort I have developed an increased general reactivity during immunization contributing to a better antigenspecific cellular response.

Data on the safety of DNA vaccines are accumulating. Neither in animals, nor in several long-term clinical trials have serious sideeffects related to genetic vaccines been noted $[67,68]$. The safety data of the novel construct CEA66-DNA was previously reported [34]. Vaccination with this construct was well tolerated and no signs of autoimmunity detected.

Lack of detectable integration of plasmid DNA into the host genome has been demonstrated preclinically, following DNA plasmids delivery by needle, needle-free devices or electroporation $[67,69]$. In the present study, two patients were diagnosed with bladder cancer during follow-up but both patients had known risk factors. Similar to previous clinical DNA vaccine trials [14,22,70-72] including CEA66DNA immunization with CEA-DNA appears to have no general safety concerns [34].

The results of our study indicate that self-tolerance against CEA could be reduced with a DNA-based vaccine, but that DNA immunization was less potent in humans than protein and/or vectorbased CEA [8-10]. A previous study demonstrated higher anti-CEA peptide responses in tumor-free CRC patients than in patients with a tumor burden, confirming that T-cell downregulating factors play a role for induction of antigen-specific cellular responses [14]. Our prime-boost concept using two different CEA-DNA vaccine constructs as in the present study did not seem to be more effective than either alone. However, a prime-boost strategy including CEA66-DNA for induction of cell mediated immunity and protein CEA for antibody induction and/or vector-based CEA may augment immune responses in humans to the same degree as seen in non-tolerant species [23,27]. Furthermore, other novel attempts to break tolerance including passive transfer of monoclonal antibodies to tumor antigens, antibodies to cell growth factors and immunoregulatory agents as immune check-point inhibitors are urgently warranted to be combined in immunization trials $[73,74]$.

\section{Conclusion}

The primary objective of the present study was to evaluate 
immunogenicity of CEA-DNA immunization in the adjuvant setting of CRC patients. Previous results with CEA protein immunization have shown promising results with improved survival for CRC patients developing high titers of anti-CEA IgG antibodies and lytic IgA antibodies $[8,75]$. We therefore attempted to complement these reactivities by a CEA plasmid CEA66-DNA, which should amplify cellular immunity together with a plasmid tetwtCEA-DNA that had preclinically induced a strong anti-CEA response. Both the CEA66DNA and tetwtCEA-DNA schedules produced non-specific activation and antigen-specific cellular responses to CEA, particularly CEA66DNA given by a needle-free jet injection, but the responses were weak. The efficacy of DNA vaccines as a stand-alone adjuvant intervention in cancer patients appears to be of limited clinical value and efforts need to be devoted to combinatorial regimens including also proteins and immune check-point inhibitors.

\section{Acknowledgements}

We thank Bo Nilsson for excellent statistical work. We thank the nurse staff of the Karolinska University Hospital for excellent clinical work. We are grateful to Richard Stout at Bioject for the provision of the Biojector device, and to former CytoPulse, New Jersey and Cellectis, Paris, for the DERMAVAX electroporation device. For excellent secretarial help, we thank Leila Relander. The skillful technical assistance of Ann Svensson, Barbro Näsman-Glaser and Ingrid Eriksson is highly appreciated.

\section{Conflict of interest}

The authors report no conflicts of interest.

\section{References}

1. Andre T, O'Neil BH, Meyerhardt JA (2012) Stage III Colon Cancer: What Works, What Doesn't and Why, and What's Next. American Society of Clinical Oncology educational book / ASCO American Society of Clinical Oncology Meeting. 223-230.

2. Melero I, Gaudernack G, Gerritsen W, Huber C, Parmiani G, et al. (2014) Therapeutic vaccines for cancer: an overview of clinical trials. Nat Rev Clin Oncol 11: 509-524. [Crossref]

3. Cheever MA, Allison JP, Ferris AS, Finn OJ, Hastings BM, et al. (2009) The prioritization of cancer antigens: a national cancer institute pilot project for the acceleration of translational research. Clin Cancer Res 15:5323-37.

4. Berinstein NL (2002) Carcinoembryonic antigen as a target for therapeutic anticancer vaccines: a review. J Clin Oncol 20: 2197-2207. [Crossref]

5. Conry RM, Allen KO, Lee S, Moore SE, Shaw DR, et al. (2000) Human autoantibodies to carcinoembryonic antigen (CEA) induced by a vaccinia-CEA vaccine. Clin Cancer Res 6: 34-41.

6. Gameiro SR, Jammeh ML, Hodge JW (2013) Cancer vaccines targeting carcinoembryonic antigen: state-of-the-art and future promise. Expert review of vaccines 12: 617-629.

7. Turriziani M, Fantini M, Benvenuto M, Izzi V, Masuelli L, et al. (2012) Carcinoembryonic antigen (CEA)-based cancer vaccines: recent patents and antitumor effects from experimental models to clinical trials. Recent Pat Anticancer Drug Discov 7: $265-296$.

8. Ullenhag GJ, Frodin JE, Jeddi-Tehrani M, Strigard K, Eriksson E, et al. (2004) Durable carcinoembryonic antigen (CEA)-specific humoral and cellular immune responses in colorectal carcinoma patients vaccinated with recombinant CEA and granulocyte/ macrophage colony-stimulating factor. Clin Cancer Res 10: 3273-81.

9. Madan RA, Bilusic M, Heery C, Schlom J, Gulley JL (2012) Clinical evaluation of TRICOM vector therapeutic cancer vaccines. Semin Oncol 39: 296-304. [Crossref]

10. Patel SP, Osada T, Lyerly HK, Morse MA (2014) Designing effective vaccines for colorectal cancer. Immunotherapy 6: 913-926. [Crossref]

11. Duggan MC, Jochems C, Donahue RN, Richards J, Karpa V, et al. (2016) A phase I study of recombinant(r) vaccinia-CEA(6D)-TRICOM and rFowlpox-CEA(6D)TRICOM vaccines with GM-CSF and IFN-alpha- $2 b$ in patients with CEA-expressing carcinomas. Cancer Immunol Immunother 65: 1353-1364.

12. Mosolits S, Nilsson B, Mellstedt H (2005) Towards therapeutic vaccines for colorectal carcinoma: a review of clinical trials. Expert Rev Vaccines 4: 329-350. [Crossref]

13. Samanci A, Yi Q, Fagerberg J, Strigard K, Smith G, et al. (1998) Pharmacological administration of granulocyte/macrophage-colony-stimulating factor is of significant importance for the induction of a strong humoral and cellular response in patients immunized with recombinant carcinoembryonic antigen. Cancer Immunol Immunother 47: 131-142.

14. McCann KJ, Mander A, Cazaly A, Chudley L, Stasakova J, et al. (2016) Targeting Carcinoembryonic Antigen with DNA Vaccination: On-Target Adverse Events Link with Immunologic and Clinical Outcomes. Clin Cancer Res 22: 4827-4836.

15. Geiben-Lynn R, Greenland JR, Frimpong-Boateng K, van Rooijen N, Hovav AH, et al. (2008) $\mathrm{CD}^{+} \mathrm{T}$ lymphocytes mediate in vivo clearance of plasmid DNA vaccine antigen expression and potentiate $\mathrm{CD} 8{ }^{+} \mathrm{T}$-cell immune responses. Blood 112: 45854590. [Crossref]

16. Ligtenberg MA, Rojas-Colonelli N, Kiessling R, Lladser A (2013) NF-kappaB activation during intradermal DNA vaccination is essential for eliciting tumor protective antigen-specific CTL responses. Hum Vaccin Immunother 9: 2189-2195.

17. Suschak JJ, Wang S, Fitzgerald KA, Lu S (2016) A cGAS-Independent STING/IRF7 Pathway Mediates the Immunogenicity of DNA Vaccines. J Immunol 196: 310-316. [Crossref]

18. Liu MA (2011) DNA vaccines: an historical perspective and view to the future. Immunol Rev 239: 62-84. [Crossref]

19. Senovilla L, Vacchelli E, Garcia P, Eggermont A, Fridman WH, et al. (2013) Tria watch: DNA vaccines for cancer therapy. Oncoimmunology 2: e23803. [Crossref]

20. Ulmer JB, Donnelly JJ, Parker SE, Rhodes GH, Felgner PL, et al. (1993) Heterologous protection against influenza by injection of DNA encoding a viral protein. Science 259 1745-1749. [Crossref]

21. Wahren B, Liu M (2014) DNA Vaccines: Recent Developments and the Future. Vaccines 2: 785-796.

22. Trimble CL, Morrow MP, Kraynyak KA, Shen X, Dallas M, et al. (2015) Safety, efficacy, and immunogenicity of VGX-3100, a therapeutic synthetic DNA vaccine targeting human papillomavirus 16 and $18 \mathrm{E} 6$ and E7 proteins for cervical intraepithelial neoplasia 2/3: a randomised, double-blind, placebo-controlled phase $2 \mathrm{~b}$ trial. Lancet 386: 2078-2088.

23. Brave A, Hallengard D, Gudmundsdotter L, Stout R, Walters R, et al. (2009) Late administration of plasmid DNA by intradermal electroporation efficiently boosts DNAprimed T and B cell responses to carcinoembryonic antigen. Vaccine 27: 3692-3296.

24. Lund LH, Andersson K, Zuber B, Karlsson A, Engstrom G, et al. (2003) Signal sequence deletion and fusion to tetanus toxoid epitope augment antitumor immune responses to a human carcinoembryonic antigen (CEA) plasmid DNA vaccine in a murine test system. Cancer Gene Ther 10: 365-376.

25. Johansson S, Ek M, Wahren B, Stout R, Liu M, et al. (2007) Intracellular targeting of CEA results in Th1-type antibody responses following intradermal genetic vaccination by a needle-free jet injection device. The Scientific World Journal 7: 987-999.

26. Johansson S, Engström G, Winberg G, Hinkula J, Wahren B (2006) Responses of mice immunized with a DNA vaccine encoding carcinoembryonic antigen (CEA). Vaccine 24: 4572-4575. [Crossref]

27. Hallermalm K, Johansson S, Brave A, Ek M, Engstrom G, et al. (2007) Pre-clinical evaluation of a CEA DNA prime/protein boost vaccination strategy against colorectal cancer. Scand J Immunol 66: 43-51. [Crossref]

28. Broderick KE, Humeau LM (2015) Electroporation-enhanced delivery of nucleic acid vaccines. Expert Rev Vaccines 14: 195-204. [Crossref]

29. Luxembourg A, Evans CF, Hannaman D (2007) Electroporation-based DNA immunisation: translation to the clinic. Expert Opin Biol Ther 7: 1647-1664. [Crossref]

30. Roos AK, Eriksson F, Timmons JA, Gerhardt J, Nyman U, et al. (2009) Skin electroporation: effects on transgene expression, DNA persistence and local tissue environment. PLoS One 4: e 7226.

31. Gothelf A, Eriksen J, Hojman P, Gehl J (2010) Duration and level of transgene expression after gene electrotransfer to skin in mice. Gene Ther 17: 839-845. [Crossref]

32. Lutsiak ME, Semnani RT, De Pascalis R, Kashmiri SV, Schlom J, et al. (2005) Inhibition of $\mathrm{CD}^{+} 25^{+} \mathrm{T}$ regulatory cell function implicated in enhanced immune response by lowdose cyclophosphamide. Blood 105: 2862-2868. 
33. Ruter J, Barnett BG, Kryczek I, Brumlik MJ, Daniel BJ, et al. (2009) Altering regulatory $T$ cell function in cancer immunotherapy: a novel means to boost the efficacy of cancer vaccines. Front Biosci (Landmark Ed) 14: 1761-1770.

34. Staff C, Mozaffari F, Haller BK, Wahren B, Liljefors M (2011) A Phase I safety study of plasmid DNA immunization targeting carcinoembryonic antigen in colorectal cancer patients. Vaccine 29: 6817-6822. [Crossref]

35. Beauchemin N, Benchimol S, Cournoyer D, Fuks A, Stanners CP (1987) Isolation and characterization of full-length functional cDNA clones for human carcinoembryonic antigen. Mol Cell Biol 7: 3221-3230. [Crossref]

36. Hammarstrom S, Baranov V (2001) Is there a role for CEA in innate immunity in the colon? Trends Microbiol 9:119-125. [Crossref]

37. Roos AK, Eriksson F, Walters DC, Pisa P, King AD (2009) Optimization of skin electroporation in mice to increase tolerability of DNA vaccine delivery to patients. Mol Ther 17: 1637-1642. [Crossref]

38. André T, Boni C, Navarro M, Tabernero J, Hickish T, et al. (2009) Improved overall survival with oxaliplatin, fluorouracil, and leucovorin as adjuvant treatment in stage II or III colon cancer in the MOSAIC trial. J Clin Oncol 27: 3109-3116. [Crossref]

39. Fioretti D, Iurescia S, Fazio VM, Rinaldi M (2010) DNA vaccines: developing new strategies against cancer. J Biomed Biotechnol 2010: 174378. [Crossref]

40. Hammarstrom S (1999) The carcinoembryonic antigen (CEA) family: structures, suggested functions and expression in normal and malignant tissues. Semin Cancer Biol 9: 67-81.

41. Tsang KY, Zaremba S, Nieroda CA, Zhu MZ, Hamilton JM, et al. (1995) Generation of human cytotoxic $\mathrm{T}$ cells specific for human carcinoembryonic antigen epitopes from patients immunized with recombinant vaccinia-CEA vaccine. $J$ Natl Cancer Inst 87: 982-990. [Crossref]

42. Mozaffari F, Lindemalm C, Choudhury A, Granstam-Björneklett H, Helander I, et al. (2007) NK-cell and T-cell functions in patients with breast cancer: effects of surgery and adjuvant chemo- and radiotherapy. Br J Cancer 97: 105-111. [Crossref]

43. Mozaffari F, Hansson L, Kiaii S, Ju X, Rossmann ED, et al. (2004) Signalling molecules and cytokine production in $\mathrm{T}$ cells of multiple myeloma-increased abnormalities with advancing stage. Br J Haematol 124: 315-324.

44. Palma M, Hansson L, Choudhury A, Nasman-Glaser B, Eriksson I, et al. (2012) Vaccination with dendritic cells loaded with tumor apoptotic bodies (Apo-DC) in patients with chronic lymphocytic leukemia: effects of various adjuvants and definition of immune response criteria. Cancer Immunol Immunother 61: 865-879. [Crossref]

45. Mosolits S, Markovic K, Frodin JE, Virving L, Magnusson CG, et al. (2004) Vaccination with Ep-CAM protein or anti-idiotypic antibody induces Th1-biased response against MHC class I- and II-restricted Ep-CAM epitopes in colorectal carcinoma patients. Clin Cancer Res 10: 5391-5402.

46. Rossmann E, Osterborg A, Lofvenberg E, Choudhury A, Forssmann U, et al. (2014) Mucin 1-specific active cancer immunotherapy with tecemotide (L-BLP25) in patients with multiple myeloma: an exploratory study. Hum Vaccin Immunother 10: 3394-3408. [Crossref]

47. Ohlsson L, Israelsson A, Öberg Å, Palmqvist R, Stenlund H, et al. (2012) Lymph node CEA and MUC2 mRNA as useful predictors of outcome in colorectal cancer. Int $J$ Cancer 130: 1833-1843. [Crossref]

48. Wahren B, Harmenberg U (1991) Tumour markers in gastrointestinal cancer. Scand $J$ Clin Lab Invest Suppl 206: 21-27. [Crossref]

49. Gold P, Freedman SO (1965) Specific carcinoembryonic antigens of the human digestive system. J Exp Med 122: 467-481. [Crossref]

50. Taheri M, Saragovi U, Fuks A, Makkerh J, Mort J, et al. (2000) Self recognition in the Ig superfamily. Identification of precise subdomains in carcinoembryonic antigen required for intercellular adhesion. J Biol Chem 275: 26935-26943. [Crossref]

51. Bodet-Milin C, Ferrer L, Rauscher A, Masson D, Rbah-Vidal L, et al. (2015) Pharmacokinetics and Dosimetry Studies for Optimization of Pretargeted Radioimmunotherapy in CEA-Expressing Advanced Lung Cancer Patients. Frontiers in medicine 2: 84. [Crossref]

52. Lutje S, Franssen GM, Sharkey RM, Laverman P, Rossi EA, et al. (2014) Anti-CEA antibody fragments labeled with [(18)F]AlF for PET imaging of CEA-expressing tumors. Bioconjug Chem 25: 335-341. [Crossref]

53. Wu AM, Yazaki PJ, Tsai S, Nguyen K, Anderson AL, et al. (2000) High-resolution
microPET imaging of carcinoembryonic antigen-positive xenografts by using a copper64-labeled engineered antibody fragment. Proc Natl Acad Sci U S A 97: 8495-500. [Crossref]

54. Hanisch FG, Schwientek T, Von Bergwelt-Baildon MS, Schultze JL, Finn O (2003) O-Linked glycans control glycoprotein processing by antigen-presenting cells: a biochemical approach to the molecular aspects of MUC1 processing by dendritic cells. Eur J Immunol 33: 3242-3254.

55. Hiltbold EM, Alter MD, Ciborowski P, Finn OJ (1999) Presentation of MUC1 tumor antigen by class I MHC and CTL function correlate with the glycosylation state of the protein taken Up by dendritic cells. Cell Immunol 194: 143-149. [Crossref]

56. Purcell AW, van Driel IR, Gleeson PA (2008) Impact of glycans on T-cell tolerance to glycosylated self-antigens. Immunol Cell Biol 86: 574-579. [Crossref]

57. Grosenbaugh DA, Leard AT, Bergman PJ, Klein MK, Meleo K, et al. (2011) Safety and efficacy of a xenogeneic DNA vaccine encoding for human tyrosinase as adjunctive treatment for oral malignant melanoma in dogs following surgical excision of the primary tumor. Am J Vet Res 72: 1631-1638.

58. Saenger YM, Li Y, Chiou KC, Chan B, Rizzuto G, et al. (2008) Improved tumor immunity using anti-tyrosinase related protein-1 monoclonal antibody combined with DNA vaccines in murine melanoma. Cancer Res 68: 9884-9891.

59. Valian HK, Rostami MN, Tasbihi M, Mohammadi AM, Eskandari SE, et al. (2013) $\mathrm{CCR}^{+}$central and $\mathrm{CCR}^{-}$effector memory $\mathrm{CD}^{+} \mathrm{T}$ cells in human cutaneous leishmaniasis. J Clin Immunol 33: 220-234.

60. Dougan M, Dranoff G (2009) Immune therapy for cancer. Annu Rev Immunol 27: 83 117. [Crossref]

61. Lollini PL, Cavallo F, Nanni P, Quaglino E (2015) The Promise of Preventive Cancer Vaccines. Vaccines (Basel) 3: 467-489. [Crossref]

62. Pico de Coaña Y, Choudhury A, Kiessling R (2015) Checkpoint blockade for cancer therapy: revitalizing a suppressed immune system. Trends Mol Med 21: 482-491. [Crossref]

63. Bracci L, Moschella F, Sestili P, La Sorsa V, Valentini M, et al. (2007) Cyclophosphamide enhances the antitumor efficacy of adoptively transferred immune cells through the induction of cytokine expression, B-cell and T-cell homeostatic proliferation, and specific tumor infiltration. Clin Cancer Res 13: 644-653.

64. Ghiringhelli F, Larmonier N, Schmitt E, Parcellier A, Cathelin D, et al. (2004) $\mathrm{CD} 4{ }^{+} \mathrm{CD} 25^{+}$regulatory $\mathrm{T}$ cells suppress tumor immunity but are sensitive to cyclophosphamide which allows immunotherapy of established tumors to be curative. Eur J Immunol 34: 336-344. [Crossref]

65. Piccirillo CA, Shevach EM (2001) Cutting edge: control of CD8 ${ }^{+} \mathrm{T}$ cell activation by $\mathrm{CD} 4^{+} \mathrm{CD} 25^{+}$immunoregulatory cells. J Immunol 167: 1137-1140. [Crossref]

66. Moschella F, Valentini M, Arico E, Macchia I, Sestili P, et al. (2011) Unraveling cancer chemoimmunotherapy mechanisms by gene and protein expression profiling of responses to cyclophosphamide. Cancer Res 71: 3528-3539.

67. Brave A, Gudmundsdotter L, Sandstrom E, Haller BK, Hallengard D, et al. (2010) Biodistribution, persistence and lack of integration of a multigene HIV vaccine delivered by needle-free intradermal injection and electroporation. Vaccine 28: 8203-209.

68. Okuda K, Wada Y, Shimada M (2014) Recent Developments in Preclinical DNA Vaccination. Vaccines (Basel) 2: 89-106. [Crossref]

69. Eschenburg G, Stermann A, Preissner R, Meyer HA, Lode HN (2010) DNA vaccination: using the patient's immune system to overcome cancer. Clin Dev Immunol 2010: 169484. [Crossref]

70. Eriksson F, Totterman T, Maltais AK, Pisa P, Yachnin J (2013) DNA vaccine coding for the rhesus prostate specific antigen delivered by intradermal electroporation in patients with relapsed prostate cancer. Vaccine 31: 3843-3848.

71. Sandstrom E, Nilsson C, Hejdeman B, Brave A, Bratt G, et al. (2008) Broad immunogenicity of a multigene, multiclade HIV-1 DNA vaccine boosted with heterologous HIV-1 recombinant modified vaccinia virus Ankara. J Infect Dis 198: 1482-1490.

72. Stevenson FK, Ottensmeier CH, Rice J (2010) DNA vaccines against cancer come of age. Curr Opin Immunol 22: 264-270. [Crossref]

73. Morse MA, Lyerly HK (2015) Checkpoint blockade in combination with cancer vaccines. Vaccine 33: 7377-7385. [Crossref] 
74. Osada T, Patel SP, Hammond SA, Osada K, Morse MA, et al. (2015) CEA/CD3bispecific $\mathrm{T}$ cell-engaging (BiTE) antibody-mediated $\mathrm{T}$ lymphocyte cytotoxicity maximized by inhibition of both PD1 and PD-L1. Cancer Immunol Immunother 64: 677-688. [Crossref]
75. Staff C, Magnusson CG, Hojjat-Farsangi M, Mosolits S, Liljefors M, et al. (2012) Induction of IgM, IgA and IgE antibodies in colorectal cancer patients vaccinated with a recombinant CEA protein. J Clin Immunol 32: 855-865. [Crossref]

Copyright: (C2017 Staff C. This is an open-access article distributed under the terms of the Creative Commons Attribution License, which permits unrestricted use, distribution, and reproduction in any medium, provided the original author and source are credited. 